\title{
PENGARUH ONLINE CONSUMER REVIEW DAN VIRAL MARKETING TERHADAP KEPUTUSAN PEMBELIAN DENGAN CONSUMER TRUST SEBAGAI INTERVENING (STUDI PADA PENGGUNA INSTAGRAM DI KECAMATAN KEBUMEN)
}

\author{
${ }^{1}$ Cucu Andita Widya G, ${ }^{2}$ Sulis Riptiono \\ S1 Manajemen, Sekolah Tinggi Ilmu Ekonomi Putra Bangsa Kebumen \\ e-mail: Anditacucu38@gmail.com
}

\begin{abstract}
This study aims to determine the effect of online consumer review and viral marketing on purchasing decisions through consumer trust as an intervening variable. The population in this study is the people in Kebumen District who have made purchases at online stores via Instagram. The research sample of 100 people with a purposive sampling method. The method used in this research is quantitative method. Data analysis using path analysis with the SPSS 22 program. The results of this study indicate that online consumer review and viral marketing have a significant effect on consumer trust. Furthermore, online consumer review has no effect on purchasing decisions, while viral marketing and consumer trust have a significant effect on purchasing decisions.
\end{abstract}

Keywords : Online Consumer Review, Viral Marketing, Consumer Trust and Purchasing Decisions

\begin{abstract}
Abstrak: Penelitian ini bertujuan untuk mengetahui pengaruh online consumer review dan viral marketing terhadap keputusan pembelian melalui consumer trust sebagai variabel intervening. Populasi dalam penelitian ini adalah masyarakat di Kecamatan Kebumen yang pernah melakukan pembelian di toko online melalui instagram. Sampel penelitian sebanyak 100 orang dengan metode purposive sampling. Metode yang digunakan dalam penelitian ini adalah metode kuantitatif. Analisis data menggunakan analisis jalur dengan program SPSS 22. Hasil penelitian ini menunjukkan bahwa online consumer review dan viral marketing berpengaruh signifikan terhadap consumer trust. Selanjutnya online consumer review tidak berpengaruh terhadap keputusan pembelian, sedangkan viral marketing dan consumer trust berpengaruh signifikan terhadap keputusan pembelian.
\end{abstract}

Kata kunci: Online Consumer Review, Viral Marketing, Consumer Trust dan Keputusan Pembelian 


\section{PENDAHULUAN}

Fenomena maraknya media sosial telah membuat beberapa pengusaha mengadopsi media sosial untuk mengakomodasi sebuah trend yang sedang berkembang. Pengusaha dituntut lebih aktif dalam melakukan pendekatan terhadap konsumen. Melalui media sosial pelaku usaha dapat membangun interaksi secara langsung dengan pelanggan, konsumen maupun calon konsumen.

Dapat kita simpulkan bahwa kesadaran akan fungsi media sosial sebagai pendukung proses pemasaran sangat tinggi. Banyaknya informasi yang dapat diakses di media sosial dengan berbagai kontennya menjadikan media sosial sebagai salah satu tempat konsumen untuk mendapatkan informasi tentang produk yang mereka butuhkan. Dari sekian banyak media sosial yaitu Facebook, Youtube, Qzone dan Tumblr, Instagram kini termasuk media sosial yang populer di Indonesia. Instagram merupakan media sosial yang digunakan oleh seseorang untuk memposting foto atau sebuah video kegiatan mereka seharihari atau aktivitas lainnya. Jumlah pengguna instagram di Indonesia terus saja mengalami kenaikan hal ini didasarkan oleh survey yang dilakukan oleh WeAresocial dan Hootsuite pada kurun waktu 2016 sampai dengan tahun 2018

\section{Pengguna Instagram di Indonesia tahun 2016-2018 (dalam Juta)}

Jumlah Pengguna Instagram $\frac{\text { Tahun }}{2016} \frac{2017}{22 \mathrm{jt}} \frac{2018}{45 \mathrm{jt}} \frac{\frac{201 \mathrm{jt}}{53}}{\frac{20}{20}}$

Sumber: Hasil Survey We Are Social dan Hootsuite 2018

Saat ini fungsi instagram tidak hanya untuk berbagi foto untuk teman dan keluarga tetapi telah bergeser sebagai media komunitas bisnis. Oleh karena itu instagram merupakan sosial media yang sangat diperhitungkan dalam berbinis. Hingga bulan November tahun 2017 tercatat ada 25 juta akun komunitas bisnis instagram yang didominasi oleh Usaha Kecil dan Menengah (UKM). Angka tersebut melonjak bila dibandingkan dengan jumlah akun komunitas bisnis sebanyak 15 juta hanya dalam hitungan sekitar 4 bulan, atau sejak bulan juli 2017 lalu (Tempo.co, 2017). Instagram digunakan beberapa orang untuk melakukan kegiatan bisnisnya yaitu jual beli secara online dengan cara memposting foto-foto produk yang mereka tawarkan kepada konsumen melalui akun bisnis mereka.

Adanya pergeseran ini juga dirasakan oleh masyarakat di Kecamatan Kebumen, berubahnya perilaku belanja masyarakat dikarenakan kesibukan mereka menuntut untuk mulai beralih dari yang sebelumnya belanja harus pergi ke toko atau pusat perbelanjaan sekarang belanja bisa dilakukan di rumah dengan mencari online shop yang banyak tersedia di media sosial.

Banyak faktor yang mempengaruhi masyarakat di kecamatan Kebumen dalam menentukan keputusan pembelian mereka pada online shop di media sosial Instagram. Sebagai bentuk komunikasi perusahaan atau toko online, konsumen juga harus diberikan wadah untuk memberikan feedback atau timbal balik berupa ulasan atas produk tersebut yang telah dibeli. Tanggapan yang dilakukan konsumen biasa disebut review konsumen atau online consumer review. Adanya review atau ulasan yang telah diberikan oleh konsumen yang telah membeli produk tersebut memberi kemudahan bagi calon konsumen dalam mencari informasi tentang produk (Kanitra dan Kusumawati, 2018). Menurut Sutanto dan Aprianingsih (2016) online consumer review adalah salah satu bentuk dari electronic word of 
mouth dan dapat dikatakan sebagai komunikasi pemasaran yang baru dan dapat mempengaruhi serta memegang peran dalam proses keputusan pembelian. Lewat cara ini konsumen dapat secara langsung berbagi informasi tentang sebuah produk kepada konsumen lainnya.

Instagram dianggap media yang paling efektif dalam melakukan promosi baik itu barang ataupun jasa. Instagram dapat mengirimkan pesan berantai yang akan disebarkan oleh orang lain secara terus menerus. Pesan berantai itulah yang disebut sebagai viral marketing (pemasaran viral) dan dapat dimanfaatkan sebagai media promosi. Viral marketing ini menitik beratkan pada bagaimana agar penyebaran informasi sebuah produk atau jasa kebanyak orang secara berantai, mewabah kebanyak pihak/konsumen yang dituju dengan menggunakan bantuan internet sebagai teknologi marketing (Wardanhi, 2011).

Gobert (dalam Hamdani dan Mawardi, 2018), mengemukakan konsep dari viral marketing ini sederhana, karena viral marketing ini merupakan turunan dari word of mouth yang menggunakan media internet. Strategi ini dilakukan dengan mengirimkan pesan tentang produk-produk yang digemari, biasanya dikirimkan untuk teman dan keluarga. Pesan tersebut dengan sendirinya akan mempromosikan merek suatu produk melalui perantara orang lain.

Faktor-faktor yang menyebabkan konsumen enggan untuk melakukan belanja online, yaitu masalah resiko, yang umumnya terkait seputar keamanan dalam pembayaran, ketakutan akan penipuan, ataupun kualitas barang yang tidak sesuai ekspektasi. Kepercayaan dan juga resiko adalah faktor yang memengaruhi keputusan pembelian pada transaksi online. Dunn (dalam Andini et al 2014) menyatakan bahwa "Trust is an intangible characteristic that allows customers $t o$ buy goods or service with the confidence that what is promised will be delivered", Artinya kepercayaan merupakan karakteristik yang tidak nampak, yang mengizinkan pelanggan untuk membeli produk dan jasa dengan keyakinan bahwa apa yang dijanjikan akan ditepati.

GAMBAR 1 Model Empiris

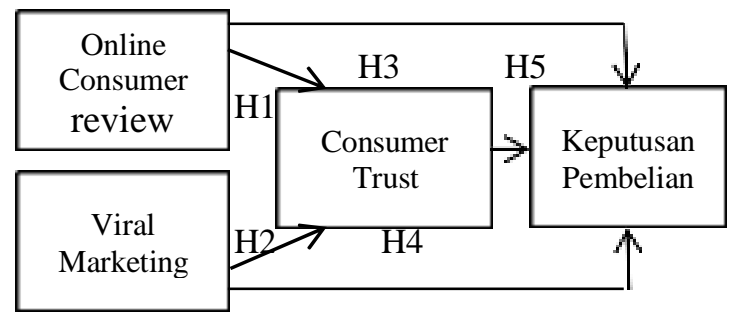

\section{METODE PENELITIAN}

Populasi dalam penelitian ini adalah pengguna Instagram di Kecamatan Kebumen. Sampel dalam penelitian ini adalah 100masyrakat di kecamatan kebumen. Teknik pengambilan sampel yang digunakan adalah nonprobability sampling dengan teknik purposive sampling. Teknik pengumpulan data yang digunakan adalah wawancara, kuesioner dan studi pustaka. Teknik analisis data yang digunakan adalah analisis deskriptif dan analisis kuantitatif dengan bantuan aplikasi komputer yaitu SPSS for Windows versi 22.0. Uji validitas dan reliabilitas digunakan untuk menguji apakah pertanyaan pada kuesioner valid dan handal.

Pengujian asumsi klasik digunakan untuk menguji kelayakan atas model regresi yang digunakan dalam penelitian dengan maksud untuk memastikan bahwa di dalam model regresi yang digunakan tidak terdapat multikolonieritas dan heteroskedastisitas serta memastikan bahwa data penelitian berdistribusi secara normal. Pengujian hipotesis digunakan untuk mengetahui bagaimana pengaruh variabelvariabel bebas terhadap variabel terikat yang pada penelitian ini menggunakan uji $t$ dan koefisien determinasi untuk mengukur kemampuan model dalam menerangkan variasi 
variabel dependen. Analisis korelasi bertujuan untuk mengukur kekuatan asosiasi (hubungan) linear antara dua variabel, sedangkan analisis jalur digunakan untuk menganalisis hubungan kausal antar variabel dengan tujuan untuk mengetahui pengaruh langsung dan tidak langsung variabel bebas terhadap variabel terikat.

\section{HASIL DAN PEMBAHASAN Uji Validitas dan Reliabilitas}

Berdasarkan hasil pengujian validitas pada, semua instrument variabel menunjukkan nilai $r_{\text {hitung }}>r_{\text {tabel }}(0,196)$. Berdasarkan hasil tersebut, dapat disimpulkan bahwa semua butir pernyataan pada setiap variabel dinyatakanvalid. Berdasarkan hasil pengujian reliabilitas, menunjukkan bahwa instrumen-instrumen yang digunakan dalam penelitian ini memiliki nilai cronbach's alpha $>$ rkritis $(0,70)$. Berdasarkan hasil tersebut, dapat disimpulkan bahwa semua instrumen dalam penelitian dinyatakan reliabel.

\section{Uji Normalitas}

Berdasarkan Uji Normalitas pada grafik histogram dan grafik normal probability plot didapatkan hasil grafik histogram menunjukan pola distribusi normal dan berbentuk simetris tidak menceng (skewness) ke kanan atau ke kiri. Serta pada grafik normal probability plot dilihat bahwa titik - titik menyebar disekitar garis diagonal, serta penyebarannya mengikuti arah garis diagonal. Dari hasil grafik tersebut dinyatakan yaitu model regresi substruktural 1 dan 2 memenuhi uji normalitas

\section{Uji Multikolonieritas}

Menurut Suliyanto (2011: 81-82), Berdasarkan Uji Multikolonieritas menyatakan tidak ada variabel yang mempunyai nilai VIF lebih besar dari 10 dan nilai tolerance lebih kecil dari 10 yang menyatakan bahwa tidak ada korelasi antara variabel bebas yang mana lebih dari 90 sehingga dapat disimpulkan bahwa tidak terjadi multikolonieritas antar variabel bebas dalam model regresi atau model regresi bebas dari multikolonieritas

\section{Hasil Uji Heteroskedastisitas}

BerdasarkanUjiHeteroskedastisitas pada scatterplot dapat dinyatakan bahwa titik - titik tersebar secara acak, diatas maupun di bawah nol pada sumbu Y dan tidak membentuk sebuah pola - pola. Maka dapat disimpulkan tidakterjadi heteroskedastisitas pada model regresi, maka model regresi mampu dan layak digunakan untuk menprediksi keputusan pembelian berdasarkan pengaruh variabel bebas.

\section{Uji Hipotesis (Uji t)}

Penelitian ini menggunakan tingkat signifikansi $5 \% \quad(\alpha=0,05)$. Dengan nilai ttabel substruktural 1 $(1,9844)$ dan nilai t tabel substruktural 2 $(1,9847)$.

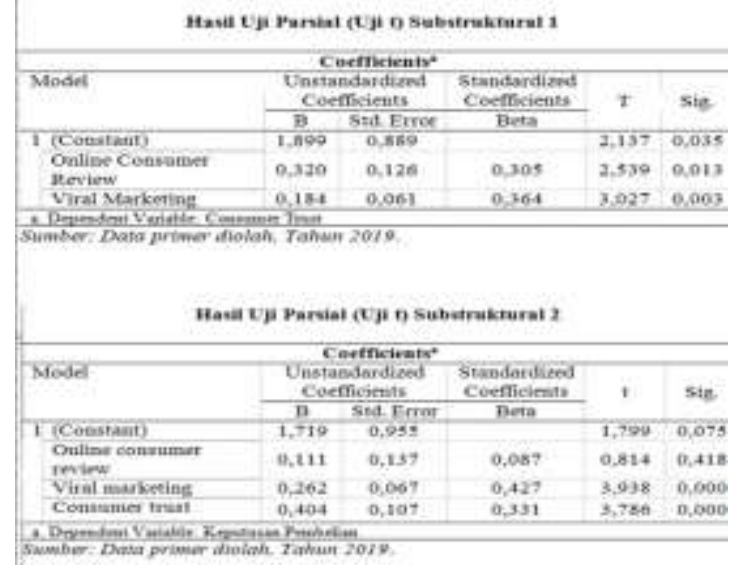

Berdasarkan tabel di atas, maka dapat disimpulkan bahwa $\mathrm{H} 1, \mathrm{H} 2, \mathrm{H} 4$ dan $\mathrm{H} 5$ diterima karena nilai thitung > tabel dengan tingkat signifikansi $<0,05$. Sedangkan $\mathrm{H} 3$ ditolak karena nilai thitung $<$ ttabel dengan tingkat signifikansi > 0,05 
Analisis Korelasi

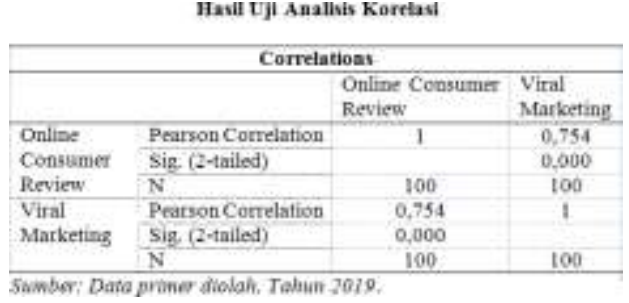

Berdasarkan hasil uji korelasi pada tabel di atas, hubungan variabel online consumer reiew dengan variabel viral marketing memiliki nilai sebesar $0,754>$ 0,5 jadi dapat disimpulkan hubungan antara dua variabel independen dalam penelitian ini memiliki korelasi sangat kuat.

\section{Koefisien Jalur}

Koefisien jalur menunjukkan kuatnya pengaruh variabel bebas terhadap variabel terikat. Koefisien jalur dapat dihitung dengan persamaan struktural yang terdiri dari dua persamaan, dimana $\mathrm{X} 1$ dan $\mathrm{X} 2$ adalah variabel eksogen, Y1 dan Y2 adalah variabel endogen.

Subtruktural 1

$$
\begin{aligned}
& \mathrm{Y} 1=\mathrm{PY} 1 \mathrm{X} 1+\mathrm{PY} 1 \mathrm{X} 2+€ 1 \\
& €_{1}=\sqrt{=\sqrt{ }=0,778} \\
& \mathrm{Y} 1=0,305 \mathrm{X} 1+0,364 \mathrm{X} 2+0,778 \\
& \text { Substruktural } 2 \\
& \mathrm{Y}_{2}=\mathrm{PY}_{2} \mathrm{X}_{1}+\mathrm{PY}_{2} \mathrm{X}_{2}+\mathrm{PY}_{2} \mathrm{Y}_{1}+€_{2} \\
& €_{2}=\sqrt{=\sqrt{ }=0,666} \\
& \mathrm{Y} 2=0,087 \mathrm{X} 1+0,427 \mathrm{X} 2+0,331 \mathrm{Y} 1 \\
& \quad+0,666
\end{aligned}
$$

Direct Effect: online consumer review terhadap consumer trust $(0,087)$ dan viral marketing terhadap consumer trust $(0,427)$. Indirect Effect: online consumer review terhadap keputusan pembelian melalui consumer trust $(0,305 \times 0,331=$ $0,100)$ dan viral marketing terhadap keputusan pembelian melalui consumer trust $(0,427 \times 0,331=0,141)$. Berdasarkan hasil DE dan IE diketahui bahwa DE < IE artinya para pengguna isntagram di kecamatan kebumen sebelum membeli produk ti online shop, konsumen akan membentuk sikap percaya dulu.

\section{Implikasi Manajerial}

1. Pengaruh online consumer review terhadap consumer trust

online consumer review berpengaruh secara signifikan terhadap variabel consumer trust pada pengguna Instagram di Kecamatan Kebumen. Semakin baik review yang diberikan oleh konsumen lain terhadap toko online maka kepercayaan konsumen juga semakin meningkat. Karena pentingnya online consumer review maka perlu untuk meningkatkan kualitas toko online dengan cara meningkatkan kredibilitas barang yang ditawarkan, agar toko online mendapatkan review yang baik dari konsumen. Hasil penelitian ini sejalan dengan penelitian yang dilakukan oleh Kanitra dan Kusumawati (2018).

2. Pengaruh viral marketing terhadap consumer trust variabel viral marketing berpengaruh secara signifikan terhadap variabel consumer trust pada pengguna Instagram di Kecamatan Kebumen. . Kepercayaan konsumen yang terbentuk dari pemasaran viral marketing dapat dikembangkan karena sekarang internet sudah sangat mudah digunakan oleh semua orang dan mayoritas sudah menjadi kebutuhan sehari-hari. Karene pentingnya viral marketing di online shop yang berada di instagram maka para pelaku bisnis online perlu meningkatkan efektifitas penggunaa dan penyebaran informasi mengenai produk yang ditawarkan melalui viral marketing terhadap peningkatan kepercayaan konsumen. Hasil penelitian ini sejalan dengan penelitian yang dilakukan oleh Hamdani dan Mawardi (2018).

3. Pengaruh online consumer review terhadap keputusan pembelian variabel online consumer review tidak berpengaruh secara signifikan terhadap variabel keputusan pembelian 
pada pengguna Instagram di Kecamatan Kebumen. Online consumer review tidak berpengaruh terhadap keputusan pembelian di karenakan review yang diberikan konsumen lain tidak sesuai dengan yang konsumen butuhkan maka para pelaku bisnis online harus lebih bisa memahami kebutuhan pasar pada saat ini. Toko online juga dapat menjalin kerja sama dengan para influencer yang berada di instagram untuk memberikan review sekaligus promosi produk yang toko online tawarkan kepada follower mereka. Hasil penelitian ini tidak sejalan dengan penelitian yang dilakukan oleh Hidayati (2018).

4. Pengaruh viral marketing terhadap keputusan pembelian

Variabel viral marketing terbukti berpengaruh secara signifikan terhadap variabel keputusan pembelian pada pengguna Instagram di Kecamatan Kebumen. Untuk meningkatkan penjualan pada belanja di toko online selain iklan yang menarik sehingga produk menjadi viral maka perlu juga kegiatan lain seperti contohnya mengadakan kuis seputar produk atau give away yang berhadiah menarik, sehingga konsumen akan terus membicarakan toko online tersebut. Sehingga dapat disimpulkan bahwa penerapan viral marketing yang baik dapat menarik calon konsumen dalam meningkatkan keputusan pembelian konsumen. Hasil penelitian ini sejalan dengan penelitian yang dilakukan oleh Purba (2016).

5. Pengaruh consumer trust terhadap keputusan pembelian variabel consumer trust berpengaruh secara signifikan terhadap variabel keputusan pembelian pada pengguna Instagram di Kecamatan Kebumen. Para pelaku bisnis online di instagram wajib terus menjaga kepercayaan konsumen salah satunya dapat dilakukan dengan memberikan garansi terhadap produk dan pelayanan yang baik kepada konsumen dengan cara mengirimkan barang tepat waktu dan barang yang dipesan sesuai dengan mereka inginkan. Melalui hal tersebut tingkat kepercayaan konsumen sangat penting untuk diperhatikan mengingat kepercayaan konsumen ternyata mempunyai pengaruh terhadap keputusan pembelian pada toko online di instagram. Hasil penelitian ini sejalan dengan penelitian yang dilakukan oleh Sahara et al (2017)

\section{Kesimpulan dan Saran Kesimpulan}

Berdasarkan hasil pembahasan analisis data melalui pembuktian terhadap hipotesis dari permasalahan yang diangkat mengenai faktor-faktor tersebut yang mempengaruhi keputusan pembelian pada pengguna Instagram di Kecamatan Kebumen, maka dapat diperoleh kesimpulan sebagai berikut:

1. Hasil penelitian menunjukkan bahwa variabel online consumer review berpengaruh dan signifikan terhadap consumer trust pada konsumen toko online melalui instagram di Kecamatan Kebumen. Hal ini berarti, review yang diberikan oleh konsumen lain secara online dapat menimbulkan kepercayaan bagi konsumen terhadap toko online di Instagram.

2. Hasil penelitian menunjukkan bahwa variabel viral marketing berpengaruh dan signifikan terhadap consumer trust pada konsumen toko online melalui instagram di Kecamatan Kebumen. Hal ini berarti bahwa penerapan strategi viral marketing yang di lakukan pada media sosial instagram dapat membantu membentuk kepercayaan konsumen, dengan semakin meningkatnya pesan viral yang diterima maka kepercayaan konsumen akan meningkat. 
3. Hasil penelitian menunjukkan bahwa variabel online consumer review tidak berpengaruh terhadap keputusan pembelian pada konsumen toko online melalui instagram di Kecamatan Kebumen. Konsumen di Kecamatan Kebumeen tidak menjadikan review yang diberikan konsumen lain dapat sebagai bahan pertimbangan untuk melakukan keputusan pembelian di toko online Instagrm.

4. Hasil penelitian menunjukkan bahwa variabel viral marketing berpengaruh dan signifikan terhadap keputusan pembelian pada konsumen toko online melalui instagram di Kecamatan Kebumen. Hal ini berarti bahwa viral marketing yang ada pada media sosial instagram membantu calon konsumen dalam melakukan suatu pengenalan kebutuhan diri sendiri, dan dapat mendorong konsumen untuk melakukankeputusan pembelian. Hasil penelitian menunjukkan bahwa variabel consumer trust berpengaruh dan signifikan terhadap keputusan pembelian pada konsumen toko online melalui instagram di Kecamatan Kebumen. Hal tersebut berarti bahwa kepercayaan konsumen yang terbentuk pada media sosial instagram, telah mampu membantu mendorong konsumen untuk melakukan suatu keputusan pembelian.

\section{Saran}

1. Penelitian ini membuktikan bahwa online consumer review berpengaruh secara signifikan terhadap consumer trust pada konsumen toko online melalui instgaram di Kecamatan Kebumen, oleh karena itu para pelaku bisnis online di instgaram tetap harus memberikan wadah bagi konsumen untuk melakukan feedback atas produk yang mereka dapatkan. dalam penelitian ini online consumer review tidak berpengaruh secara signifikan terhadap keputusan pembelian, walaupun demikian toko online di instagram harus tetap memperhatikan online consumer review sebagai bentuk komunikasi yang diberikan konsumen terhadap produk yang toko online tawarkan. Diharapkan pelaku bisnis online di instagram dapat lebih memperhatikan dan mempelajari hal-hal yang berhubungan dengan online consumer review, karena variabel online consumer review mempunyai pengaruh yang signifikan terhadap keputusan pembelian, diantaranya dengan cara memahami dan meningkatkan kerja sama dengan para influencer untuk memberikan review produk yang ditawarkan dengan memanfaatkan para selebgram secara aktif maka akan menampilkan konsep online consumer review yang sesuai dengan produk toko online sehingga keputusan pembelian akan dan kepercayaan konsumen semakin baik.

2. Penelitian ini membuktikan bahwa viral marketing berpengaruh secara signifikan terhadap consumer trust dan keputusan pembelian pada konsumen toko online melalui instagram di Kecamatan Kebumen. karena variabel viral marketing terbukti mempunyai pengaruh yang signifikan terhadap kepercayaan konsumen dan keputusan pembelian, diantaranya yaitu dengan lebih meningkatkan kualitas pelayanan yang diberikan kepada konsumen, menyediakan informasi contac person yang jelas sehingga konsumen dapat dengan mudah untuk menghubungi 
penjual, lebih kreatif dan berinovasi dalam upaya menarik perhatian konumen, mengadakan kegiatan promosi serta kegiatan lain yang menarik dalam upaya menarik konsumen dan meningkatkan kualitas tampilan foto atau video yang ditampilkan dalam instagram, sehingga akan meningkatkan keputusan pembelianpada calon konsumen di instagram.

3. Penelitian selanjutnya di harapkan untuk lebih memperluas lingkup dari penelitian ini, tidak hanya berfokus kembali pada Kecamatan Kebumen saja dan sebaiknya peneliti selanjutnya dapat menambahkan variabel lain pada penelitian yang serupa seperti variabel keanekaragaman produk dan celebrity endorments agar dapat memperkaya kajian dalam penelitian serupa serta agar pembaca dapat mengetahui variabel lainnya yang dapat mempengaruhi keputusan pembelian konsumen di toko online instagram.

\section{REFERENSI}

Admin. 2017. "Pengguna Instagram di Indonesia Mencapai 45 Juta". Diambil dari https://bali.antaranews.com/berita/ 108986/pengguna-instagram-diindonesia-mencapai-45-juta

Andini, N.P., Suharyono dan Sunarti. 2014. "Pengaruh Viral Marketing Terhadap Kepercayaan Pelanggan dan Keputusan Pembelian (Studi Pada Mahasiswa Fakultas Ilmu Administrasi Universitas Brawijaya Angkatan 2013 yang Melakukan Pembelian Online Melalui Media Sosial Instagram)".
Jurnal Administrasi Bisnis (JAB), Vol. 11 No. 1, Juni 2014.

Hamdani, M.Y., dan Mawardi, Kholid. 2018. "Pengaruh Viral Marketing Terhadap Kepercyaan Konsumen Serta Dampaknya Terhadap keputusan Pembelian (Survey pada Mahasiswa Fakultas Ilmu Administrasi Universitas Brawijaya Angkatan 2015/2016 yang pernah Melakukan Pembelian Online melalui Media Sosial Instgram)". Jurnal Administrasi Bisnis (JAB), Vol. 60 No. 1, Juli 2018.

Kanitra, A.R., dan Andriani, K. 2018. "Pengaruh Country Of Origin dan Online Consumer Review Terhadap Trust dan Keputusan Pembelian (Survey Pada Mahasiswa S1 fakultas Ilmu Administrasi Universitas Brawijaya Angkatan 2015/2016 dan 2016/2017 Tahun Akademik 2017/2018 Pembelian Produk Oppo Smartphone)". Jurnal Administrasi Bisnis (JAB), Vol. 61 No. 1, Agustus 2018.

Suliyanto. 2011. Ekonometrika Terapan: Teori Dan Aplikasi Dengan SPSS. Yogyakarta: Andi.

Sutanto, Monica. A, dan Aprianingsih, A. 2016. "The Effect of Online Consumer Review Toward Purchase Intention: a Study in Premium Cosmetic in Indonesia". Proceeding International Conference on Ethics of Business, Economics, and Social Science. 2016, 2528-617X.

Wardanhi, sartika sari. 2011. "Strategi Viral Marketing Im3 Indosat Dalam Menarik Pelanggan Kawula 
Jurnal IImiah Mahasiswa Manajemen, Bisnis dan Akuntansi Vol. 1, No. 1, Oktober 2019

Muda Di Makassar". Jurnal

Komunikasi KAREBA, Vol. 1, No.

4 Desember 2011. 